Brit. Heart $\mathcal{F}$, 1966, 28, 118.

\title{
Serial Determinations of Cardiac Output at Rest
}

\author{
GUNNAR GRIMBY, NILS JOHAN NILSSON, AND HARALD SANNE \\ From the Department of Clinical Physiology, University of Göteborg, Sweden
}

Several reports have been published on cardiac output at rest in normal man (for a review see Wade and Bishop, 1962), but in most studies there are only a few measurements in each subject. Thus, our knowledge of the variation in cardiac output during prolonged rest is very limited (e.g. Bruce and Shillingford, 1962). The present investigation aims at analysing, first, the absolute value and variability of the cardiac output as judged from a series of determinations in the same subject and, secondly, the probability of systematic changes in cardiac output during resting conditions in a laboratory routine. The effects of disturbances and of breathing through a mouthpiece were also studied. For such an investigation, the method must allow a series of determinations without change in circulatory blood volume. The dye dilution technique, using a cuvette densitometer and reinfusion of the withdrawn blood after the recording of each curve, is therefore suitable, provided the indicator used is harmless for the patient.

\section{SubJECTS AND METHOdS}

A group of clinically healthy male volunteers was investigated, age range 21-39 years. They were students or blood donors and had been well informed about the experimental procedure at a clinical examination some days earlier.

The subjects arrived at the department in the morning, having eaten a light meal. Polyethylene tubes were inserted percutaneously into the brachial arteries and into a peripheral arm vein (Bernéus et al., 1954), usually with the tip of the catheter near the subclavian vein. The subjects then rested in the supine position for about an hour before the observations started.

Cardiac output was determined with the dye dilution technique, using Cardio-green ${ }^{\star}$ as an indicator. Usually $5 \mathrm{mg}$. dye in $1 \mathrm{ml}$. of distilled water was injected into the venous catheter from a tuberculin syringe, and this was immediately followed by 6-8 ml. of saline. Blood was withdrawn from an arterial catheter through a specially

Received March 29, 1965.

* Manufactured by Hynson, Westcott and Dunning, Baltimore, Md., U.S.A. developed cuvette densitometer (Nilsson, 1963), used with an Atlas oximeter (Nilsson, 1956): the change in optical density of the blood during the passage of the dye was recorded on a potentiometer recorder (Micrograph BD3, Kipp and Zonen, Delft). The blood was reinfused after each recording.

The intra-arterial blood pressure was recorded with an inductance manometer (Elema, Stockholm) simultaneously with the recording of the dye dilution curves.

Cardiac output, heart rate, and arterial blood pressure were determined 10 times at five-minute intervals. The subjects were then given a mouthpiece for collecting the expired air in Douglas bags, and observations were made 50 and 52 minutes after the beginning of the experiment. The expired air was analysed with the Scholander method. Efforts were made to maintain a calm and silent environment. However, disturbing incidents occurred in some cases, as reported below.

\section{RESULTS}

Table I gives the cardiac output determined 10 times at five-minute intervals. The variation coefficients in the 14 subjects ranged from 5 to 14 per cent (mean $8.6 \%$ ). There was no significant difference between the first two values, neither was there any significant change from the first two values to the last two in the 45-minute series. A rhythmic variation in cardiac output was noted in 7 subjects, with an interval of about 20 minutes between the maxima. There was nothing to show that the maxima occurred a certain time after the beginning of the observations. Further prolonged studies are necessary to determine whether these observations express some kind of biological rhythm or whether they are ascribable to chance, to the laboratory procedure, or to some other external cause.

For the period when expired air was collected, the cardiac output in 12 of 14 subjects was higher than the average during the period without a mouthpiece. The average difference $0.20 \mathrm{l} . / \mathrm{min} . \mathrm{m}^{2}$ was significant $(\mathrm{p}<0.05)$. The oxygen uptake averaged 115 per cent (range 94-162) of the predicted basal metabolism, according to Harris and 


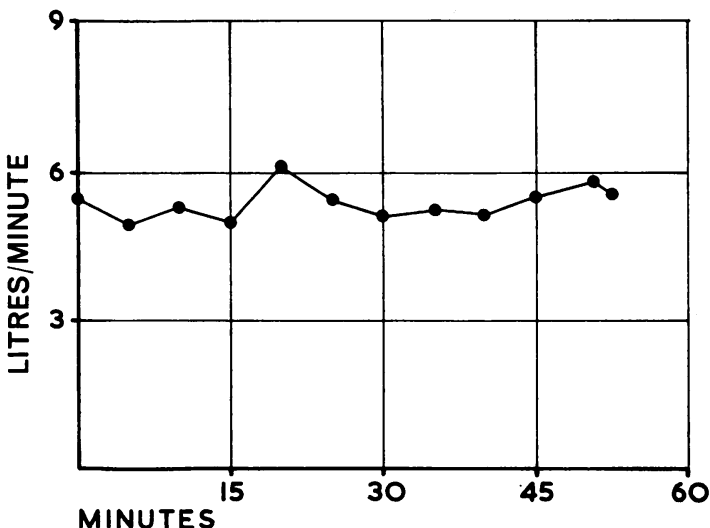

FIG. 1.-Cardiac output values in subject B.W. Average variability. No external disturbances. The last two determinations were made during the collection of expired air, i.e. with mouthpiece inserted.

Figure 1 illustrates the results in subject B.W., in whom variations were about average. The investigation of some subjects was accompanied by disturbances, such as persons accidentally entering the room and talking loudly, or other sudden noises. The results from such experiments are not included in Table I. Fig. 2 illustrates such an investigation, showing increases in cardiac output occurring simultaneously with the noise in the room. Table II gives the means of 10 determinations and their standard deviations, in each individual, for cardiac output, cardiac index, heart rate, stroke volume, and mean arterial pressure. The average cardiac index for all the subjects was $3 \cdot 181 . / \mathrm{min} . \mathrm{m}^{2}$ (S.D. 0.27). The observations during the measurement of oxygen uptake are reported in Table III.

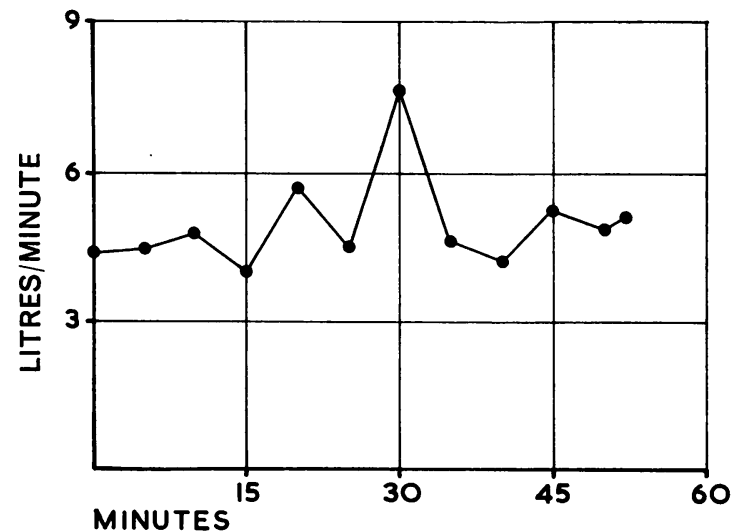

Fig. 2.-Influence of external disturbances. Cardiac output values in subject G.K. (not included in the case material). At 20 minutes a loud conversation took place; shortly before 30 minutes a mechanic entered and started hammering on an apparatus in the room.

\section{Discussion}

The literature is deficient in studies on the repeatability of the indicator dilution technique with many determinations in the same subject. In this investigation no systematic change in the cardiac output was found during the 45-minute observation period, though some subjects showed a tendency to a rhythmic variation. In several other reports (see Wade and Bishop, 1962) the second of two determinations was found to be lower than the first. This was the case also in Bruce and Shillingford's (1962) study which comprised 3-8 determinations during periods up to 40 minutes, and revealed a fall from the first to the second determination in the hospital patients studied but not in the group of

TABLE I

CARDIAC OUTPUT (1./min.) AT FIVE-MINUTE INTERVALS

\begin{tabular}{|c|c|c|c|c|c|c|c|c|c|c|c|c|c|}
\hline \multirow[t]{2}{*}{ Initials } & \multicolumn{10}{|c|}{ Minutes } & \multirow[t]{2}{*}{ Mean } & \multirow[t]{2}{*}{ S.D. } & \multirow{2}{*}{$\begin{array}{c}\text { Variation } \\
\text { coefficient } \\
\text { per cent }\end{array}$} \\
\hline & 0 & 5 & 10 & 15 & 20 & 25 & 30 & 35 & 40 & 45 & & & \\
\hline $\begin{array}{l}\text { G.W. } \\
\text { B.W. } \\
\text { A.E. } \\
\text { H.St. } \\
\text { H.E. } \\
\text { T.H. } \\
\text { C.L.. } \\
\text { K.A.B. } \\
\text { F.Kj. } \\
\text { B.J. } \\
\text { R.Hv. } \\
\text { E.R. } \\
\text { K.O.J. } \\
\text { L.O.J. }\end{array}$ & $\begin{array}{l}5 \cdot 56 \\
5 \cdot 46 \\
6 \cdot 40 \\
8 \cdot 22 \\
5 \cdot 25 \\
4 \cdot 65 \\
7 \cdot 16 \\
6 \cdot 70 \\
6 \cdot 60 \\
6 \cdot 27 \\
5 \cdot 30 \\
6 \cdot 16 \\
4 \cdot 70 \\
6 \cdot 76\end{array}$ & $\begin{array}{l}5 \cdot 24 \\
4 \cdot 92 \\
6 \cdot 40 \\
8 \cdot 14 \\
5 \cdot 75 \\
4 \cdot 84 \\
8 \cdot 88 \\
6 \cdot 45 \\
5 \cdot 78 \\
6 \cdot 66 \\
5 \cdot 38 \\
6 \cdot 21 \\
5 \cdot 01 \\
6 \cdot 78\end{array}$ & $\begin{array}{l}5 \cdot 23 \\
5 \cdot 25 \\
8 \cdot 13 \\
8 \cdot 28 \\
5 \cdot 31 \\
4 \cdot 95 \\
7 \cdot 02 \\
6 \cdot 96 \\
6 \cdot 43 \\
5 \cdot 99 \\
6 \cdot 16 \\
6 \cdot 47 \\
5 \cdot 36 \\
7 \cdot 49\end{array}$ & $\begin{array}{l}4 \cdot 57 \\
4.96 \\
7 \cdot 06 \\
8 \cdot 11 \\
4 \cdot 48 \\
4.62 \\
8 \cdot 02 \\
6 \cdot 48 \\
8.02 \\
7 \cdot 34 \\
6.35 \\
5 \cdot 78 \\
5.08 \\
6.63\end{array}$ & $\begin{array}{l}5 \cdot 38 \\
6 \cdot 10 \\
6 \cdot 00 \\
9 \cdot 09 \\
5 \cdot 10 \\
4 \cdot 42 \\
6 \cdot 64 \\
7 \cdot 30 \\
6 \cdot 56 \\
6 \cdot 61 \\
6 \cdot 68 \\
5 \cdot 48 \\
6.64 \\
6.46\end{array}$ & $\begin{array}{l}5 \cdot 31 \\
5 \cdot 38 \\
7 \cdot 10 \\
7 \cdot 67 \\
4 \cdot 80 \\
4 \cdot 56 \\
7 \cdot 62 \\
6 \cdot 60 \\
8 \cdot 28 \\
6 \cdot 82 \\
6 \cdot 00 \\
6 \cdot 23 \\
5 \cdot 22 \\
7 \cdot 16\end{array}$ & $\begin{array}{l}5 \cdot 07 \\
5 \cdot 03 \\
7 \cdot 94 \\
6 \cdot 98 \\
5 \cdot 14 \\
4 \cdot 39 \\
6 \cdot 52 \\
7 \cdot 50 \\
6 \cdot 52 \\
7 \cdot 02 \\
5 \cdot 88 \\
6 \cdot 54 \\
5 \cdot 37 \\
8 \cdot 33\end{array}$ & $\begin{array}{l}4 \cdot 88 \\
5 \cdot 25 \\
6 \cdot 31 \\
7 \cdot 92 \\
5 \cdot 64 \\
5 \cdot 69 \\
6 \cdot 90 \\
5 \cdot 96 \\
6 \cdot 54 \\
6 \cdot 84 \\
5 \cdot 49 \\
6 \cdot 07 \\
6 \cdot 16 \\
7 \cdot 04\end{array}$ & $\begin{array}{l}5 \cdot 74 \\
5 \cdot 16 \\
6 \cdot 49 \\
8 \cdot 00 \\
5 \cdot 31 \\
4 \cdot 15 \\
6 \cdot 48 \\
5 \cdot 70 \\
8 \cdot 94 \\
7 \cdot 28 \\
5 \cdot 80 \\
6 \cdot 32 \\
5 \cdot 13 \\
7 \cdot 03\end{array}$ & $\begin{array}{l}5 \cdot 60 \\
5 \cdot 46 \\
6 \cdot 62 \\
7 \cdot 74 \\
5 \cdot 46 \\
3 \cdot 56 \\
7 \cdot 06 \\
6 \cdot 50 \\
7 \cdot 32 \\
6 \cdot 22 \\
6 \cdot 13 \\
6 \cdot 36 \\
5.03 \\
7 \cdot 34\end{array}$ & $\begin{array}{l}5 \cdot 26 \\
5 \cdot 30 \\
6 \cdot 85 \\
8 \cdot 02 \\
5 \cdot 22 \\
4 \cdot 58 \\
7 \cdot 23 \\
6 \cdot 62 \\
7 \cdot 10 \\
6 \cdot 71 \\
5 \cdot 92 \\
6 \cdot 16 \\
5 \cdot 37 \\
7 \cdot 10\end{array}$ & $\begin{array}{l}0.35 \\
0.34 \\
0.71 \\
0.53 \\
0.38 \\
0.55 \\
0.75 \\
0.55 \\
1.00 \\
0.45 \\
0.44 \\
0.32 \\
0.59 \\
0.54\end{array}$ & $\begin{array}{r}6 \cdot 7 \\
6.5 \\
10 \cdot 4 \\
6 \cdot 7 \\
7 \cdot 2 \\
12.0 \\
10 \cdot 4 \\
8 \cdot 3 \\
14 \cdot 1 \\
6.7 \\
7 \cdot 4 \\
5 \cdot 1 \\
10.9 \\
7.5\end{array}$ \\
\hline Mean & 6.09 & $6 \cdot 17$ & $6 \cdot 36$ & $6 \cdot 25$ & $6 \cdot 32$ & $6 \cdot 34$ & $6 \cdot 30$ & $6 \cdot 19$ & $6 \cdot 25$ & $6 \cdot 17$ & $6 \cdot 24$ & 0.54 & 8.6 \\
\hline
\end{tabular}


TABLE II

MEAN VALUES AND STANDARD DEVIATIONS FOR 10 DETERMINATIONS WITH AN INTERVAL OF 5 MINUTES (no mouthpiece)

\begin{tabular}{|c|c|c|c|c|c|}
\hline Initials & $\underset{\text { (1./min.) }}{\text { Cardiac output }}$ & $\begin{array}{l}\text { Cardiac index } \\
\left(1 . / \mathrm{min} . \mathrm{m} .{ }^{2}\right)\end{array}$ & $\begin{array}{c}\text { Heart rate } \\
\text { (beats/min.) }\end{array}$ & $\begin{array}{c}\text { Stroke volume } \\
\text { (ml.) }\end{array}$ & \begin{tabular}{|c} 
Mean arterial pressure \\
$(\mathrm{mm} . \mathrm{Hg})$
\end{tabular} \\
\hline G.W. & $\begin{array}{l}5 \cdot 26 \\
0.35\end{array}$ & $\begin{array}{l}2 \cdot 75 \\
0.18\end{array}$ & $\begin{array}{l}60 \\
1.5\end{array}$ & $\begin{array}{c}88 \\
4.9\end{array}$ & $\begin{array}{l}86 \\
3.5\end{array}$ \\
\hline B.w. & $\begin{array}{l}5.30 \\
0.34\end{array}$ & $\begin{array}{l}2.70 \\
0.17\end{array}$ & $\begin{array}{l}56 \\
2 \cdot 6\end{array}$ & $\begin{array}{l}95 \\
5 \cdot 3\end{array}$ & $\begin{array}{l}86 \\
3.9\end{array}$ \\
\hline A.E. & $\begin{array}{l}6.85 \\
0.71\end{array}$ & $\begin{array}{l}3.62 \\
0.38\end{array}$ & $\begin{array}{l}80 \\
6 \cdot 3\end{array}$ & $\begin{array}{l}86 \\
6.9\end{array}$ & $\begin{array}{l}78 \\
2 \cdot 7\end{array}$ \\
\hline H.St & $\begin{array}{l}8.02 \\
0.53\end{array}$ & $\begin{array}{l}3.85 \\
0.26\end{array}$ & $\begin{array}{l}73 \\
3 \cdot 2\end{array}$ & ${ }_{6.9}^{110}$ & $\begin{array}{l}78 \\
2 \cdot 7\end{array}$ \\
\hline H.E. & $\begin{array}{l}5 \cdot 22 \\
0 \cdot 38\end{array}$ & $\begin{array}{l}2 \cdot 81 \\
0 \cdot 20\end{array}$ & $\begin{array}{l}66 \\
2 \cdot 0\end{array}$ & $\begin{array}{l}80 \\
5.6\end{array}$ & $\begin{array}{l}73 \\
2 \cdot 4\end{array}$ \\
\hline T.H. & $\begin{array}{l}4.58 \\
0.55\end{array}$ & $\begin{array}{l}2 \cdot 28 \\
0.27\end{array}$ & $\begin{array}{l}54 \\
1 \cdot 1\end{array}$ & $\begin{array}{l}86 \\
10.5\end{array}$ & $\begin{array}{l}83 \\
3 \cdot 4\end{array}$ \\
\hline C.L. & $\begin{array}{l}7.23 \\
0.75\end{array}$ & $\begin{array}{l}3.33 \\
0.35\end{array}$ & $\begin{array}{l}68 \\
2 \cdot 2\end{array}$ & $\stackrel{107}{11.9}$ & $\begin{array}{l}84 \\
2.5\end{array}$ \\
\hline K.Å.B. & $\begin{array}{l}6.62 \\
0.27\end{array}$ & $\begin{array}{l}3.34 \\
0.28\end{array}$ & $\begin{array}{c}63 \\
4 \cdot 2\end{array}$ & $\begin{array}{c}106 \\
10 \cdot 4\end{array}$ & $\begin{array}{l}95 \\
2 \cdot 4\end{array}$ \\
\hline F.Kj. & $\begin{array}{l}7.10 \\
1.00\end{array}$ & $\begin{array}{l}3.72 \\
0.53\end{array}$ & $\begin{array}{l}72 \\
3.6\end{array}$ & $\begin{array}{l}96 \\
15.8\end{array}$ & $\stackrel{108}{0.7}$ \\
\hline B.J. & $\begin{array}{l}6 \cdot 71 \\
0.45\end{array}$ & $\begin{array}{l}3.65 \\
0.24\end{array}$ & $\begin{array}{l}59 \\
4.8\end{array}$ & ${ }_{11}^{116} \cdot 0$ & $\begin{array}{l}93 \\
1.4\end{array}$ \\
\hline R.Hv. & $\begin{array}{l}5.92 \\
0.44\end{array}$ & $\begin{array}{l}2.85 \\
0.21\end{array}$ & $\begin{array}{l}65 \\
1 \cdot 3\end{array}$ & $\begin{array}{l}91 \\
6 \cdot 8\end{array}$ & $\begin{array}{l}77 \\
2 \cdot 9\end{array}$ \\
\hline E.R. & $\begin{array}{l}6 \cdot 16 \\
0 \cdot 32\end{array}$ & $\begin{array}{l}3.33 \\
0.18\end{array}$ & $\begin{array}{c}62 \\
0.7\end{array}$ & $\begin{array}{l}98 \\
5 \cdot 2\end{array}$ & $\begin{array}{l}90 \\
5.9\end{array}$ \\
\hline K.o.J. & $\begin{array}{l}5 \cdot 37 \\
0.33\end{array}$ & $\begin{array}{l}2.87 \\
0.31\end{array}$ & $\begin{array}{l}57 \\
2.9\end{array}$ & $\begin{array}{l}95 \\
8.8\end{array}$ & $\begin{array}{l}92 \\
2.7\end{array}$ \\
\hline L.O.J. & $\begin{array}{l}7.10 \\
0.54\end{array}$ & $\begin{array}{l}3.50 \\
0.26\end{array}$ & $\begin{array}{l}67 \\
6.0\end{array}$ & $\begin{array}{c}107 \\
6.5\end{array}$ & $\begin{array}{l}113 \\
1.9\end{array}$ \\
\hline
\end{tabular}

TABLE III

MEAN VALUES FOR TWO DETERMINATIONS WITH A TWO-MINUTE INTERVAL DURING DETERMINATION OF OXYGEN UPTAKE

\begin{tabular}{|c|c|c|c|c|c|}
\hline Initials & $\begin{array}{l}\text { Oxygen uptake } \\
\text { (ml./min.) }\end{array}$ & $\begin{array}{c}\text { Cardiac output } \\
(1 . / \mathrm{min} .)\end{array}$ & $\begin{array}{c}\text { Heart rate } \\
\text { (beats/min.) }\end{array}$ & $\begin{array}{l}\text { Stroke volume } \\
\text { (ml.) }\end{array}$ & $\begin{array}{c}\text { Mean arterial pressure } \\
(\mathrm{mm} . \mathrm{Hg})\end{array}$ \\
\hline $\begin{array}{l}\text { G.W. } \\
\text { B.W. } \\
\text { A.E. } \\
\text { H.St. } \\
\text { H.E. } \\
\text { T.H. } \\
\text { C.L. } \\
\text { K.A.B. } \\
\text { F.Kj. } \\
\text { B.J. } \\
\text { R.H. } \\
\text { E.R. } \\
\text { K.O.J. } \\
\text { L.O.J. }\end{array}$ & $\begin{array}{c}305 \\
297 \\
268 \\
266 \\
289 \\
247 \\
303 \\
346 \\
392 \\
298 \\
287 \\
245 \\
\text { failed } \\
323\end{array}$ & $\begin{array}{l}5 \cdot 70 \\
5 \cdot 73 \\
6 \cdot 20 \\
8 \cdot 77 \\
5 \cdot 40 \\
4.77 \\
8.58 \\
6.00 \\
7 \cdot 95 \\
6 \cdot 81 \\
6 \cdot 07 \\
6.90 \\
5 \cdot 33 \\
7 \cdot 71\end{array}$ & $\begin{array}{l}62 \\
54 \\
74 \\
72 \\
70 \\
54 \\
70 \\
60 \\
81 \\
56 \\
67 \\
63 \\
53 \\
83\end{array}$ & $\begin{array}{r}92 \\
106 \\
84 \\
122 \\
78 \\
88 \\
123 \\
101 \\
98 \\
122 \\
90 \\
110 \\
101 \\
93\end{array}$ & $\begin{array}{r}92 \\
84 \\
82 \\
83 \\
79 \\
88 \\
86 \\
94 \\
110 \\
93 \\
82 \\
92 \\
94 \\
121\end{array}$ \\
\hline
\end{tabular}

physicians, indicating an influence on the cardiac output from apprehension. The variation in 8 subjects during 40 -minute periods was the same as or somewhat larger than in the present investigation. Thus, the use of arterial and venous catheters for direct recording of the concentration of the dye in arterial blood does not seem to dis- turb the examined person more than an oximeter earpiece and two indwelling needles. The observation that cardiac output can be easily increased by even slight external disturbance is confirmed in our study. Studies in patients have shown that breathing through a mouthpiece can cause disturbance. As this procedure for collecting expired 
air is used in the Fick method and often in connexion with the indicator dilution technique, there were practical reasons for analysing its effect. In most subjects the cardiac output increased somewhat (average $6 \%$ ), but some showed no or a negligible change. The oxygen uptake was only somewhat higher than the predicted basal metabolism, and it can therefore be assumed that most subjects were in a near basal state during the investigation proper, i.e. before the collection of air was begun.

The average cardiac index of $3 \cdot 18 \mathrm{l} . / \mathrm{min} . \mathrm{m}^{2}$ in this group of healthy young men conforms well with other reports as reviewed by Wade and Bishop (1962). The variation coefficients in this study, calculated from 10 observations during 45 minutes, average 8.6 per cent. This figure includes methodological as well as biological variations. In a previous investigation using the same technique, the error for a single determination was estimated from 18 duplicate determinations and found to be 6.2 per cent (Grimby and Nilsson, 1963). The variation in cardiac output seems to be somewhat higher in the prolonged series, but the values are often fairly stable during the period. In view of the ease with which cardiac output can be disturbed, it seems probable that a not insignificant part of the observed variability is caused by actual changes in the cardiac output, as distinct from variations of method.

The technique reported here is well suited for studies requiring repeated determinations of cardiac output. Cardio-green can be injected several times within a short period without giving any significant increase in blood concentration (Edwards et al., 1960). It is also recommended that the densitometer used is linear over a large range of dye concentrations (Nilsson, 1963). Furthermore, it is important that blood is reinfused after each recording in order to keep the blood volume practically constant.

\section{SUMMARY}

Cardiac output was determined in a group of healthy volunteers, age range 21-39 years, using the dye-dilution technique with Cardio-green as an indicator, a direct recording system, and reinfusion of the blood after each recording. Ten determinations at five-minute intervals gave a mean cardiac index in 14 subjects of $3.18 \mathrm{l} . / \mathrm{min} . \mathrm{m}^{2}$ The average coefficient of variation was 8.6 per cent. Thereafter two determinations were made during the collection of expired air. No systematic change occurred during the 45-minute period, but when the subjects breathed through the mouthpiece for determination of oxygen uptake there was a small $(6 \%)$ increase in cardiac output. An example is also given of experiments where disturbances caused a more marked variation in cardiac output. The technique used in this investigation is well suited for studies where changes in cardiac output have to be followed with repeated determinations.

This study was supported by a grant from the Swedish National Association against Heart and Chest Diseases.

\section{REFERENCES}

Bernéus, B., Carlsten, A., Holmgren, A., and Seldinger, S. I. (1954). Percutaneous catheterization of peripheral arteries as a method for blood sampling. Scand. $\mathcal{F}$. clin. Lab. Invest., 6, 217.

Bruce, T. A., and Shillingford, J. P. (1962). The normal resting cardiac output: serial determinations by a dye dilution method. Brit. Heart f., 24, 69.

Edwards, A. W. T., Bassingthwaighte, J. B., Sutterer, W. F., and Wood, E. H. (1960). Blood level of indocyanine green in the dog during multiple dye curves and its effect on instrumental calibration. Proc. Mayo Clin., 35, 745.

Grimby, G., and Nilsson, N. J. (1963). Cardiac output during exercise in pyrogen-induced fever. Scand. $\mathcal{F}$. clin. Lab. Invest., 15, Suppl. 69, p. 44.

Harris, J. A., and Benedict, F. G. (1919). A Biometric Study of Basal Metabolism in Man. Carnegie Institute, Washington. [Publ. No. 279].

Nilsson, N. J. (1956). Ein linear anzeigendes Oximeter. Pflïgers Arch. ges. Physiol., 263, 374.

- (1963). A linearly responding dichromatic cuvette densitometer for dye-dilution curves. Scand. F. clin. Lab. Invest., 15, Suppl. 69, p. 181.

Wade, O. L., and Bishop, J. M. (1962). Cardiac Output and Regional Blood Flow. Blackwell Scientific Publications, Oxford. 